This item was submitted to Loughborough's Institutional Repository (https://dspace.lboro.ac.uk/) by the author and is made available under the following Creative Commons Licence conditions.

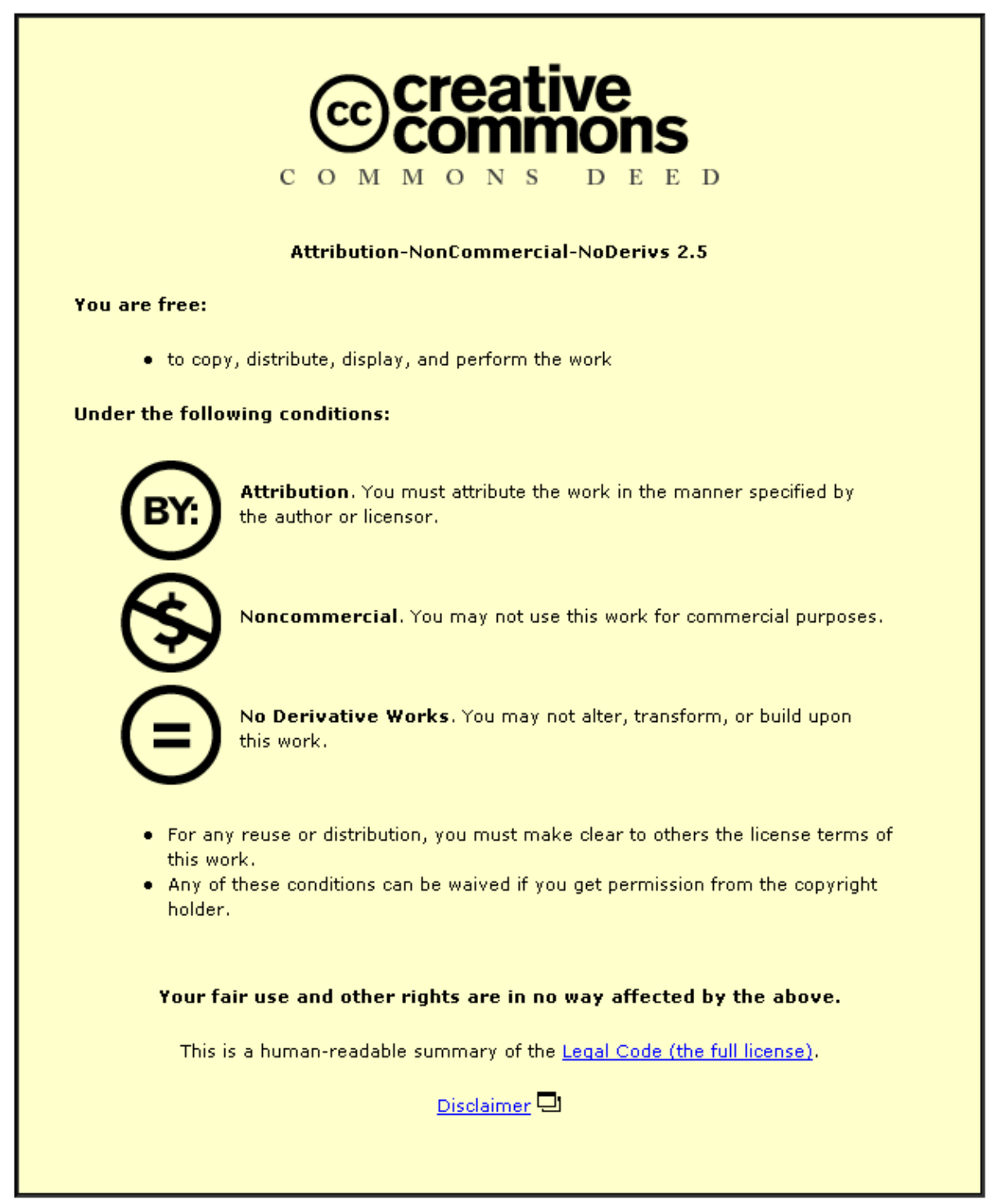

For the full text of this licence, please go to: http://creativecommons.org/licenses/by-nc-nd/2.5/ 


\section{Accepted Manuscript}

Title: Ranking of interventions to reduce dwelling overheating during heat waves

Authors: S.M. Porritt, P.C. Cropper, L. Shao, C.I. Goodier

PII: $\quad$ S0378-7788(12)00089-8

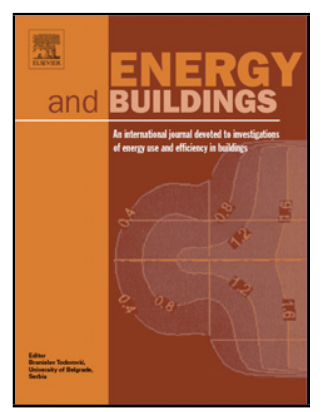

DOI: doi:10.1016/j.enbuild.2012.01.043

Reference: $\quad$ ENB 3606

To appear in: $\quad E N B$

Received date: $\quad 2-4-2011$

Revised date: 27-1-2012

Accepted date: $\quad$ 28-1-2012

Please cite this article as: S.M. Porritt, P.C. Cropper, L. Shao, C.I. Goodier, Ranking of interventions to reduce dwelling overheating during heat waves, Energy and Buildings (2010), doi:10.1016/j.enbuild.2012.01.043

This is a PDF file of an unedited manuscript that has been accepted for publication. As a service to our customers we are providing this early version of the manuscript. The manuscript will undergo copyediting, typesetting, and review of the resulting proof before it is published in its final form. Please note that during the production process errors may be discovered which could affect the content, and all legal disclaimers that apply to the journal pertain. 


\title{
Ranking of interventions to reduce dwelling overheating during heat waves
}

\author{
Authors
}

S. M. Porritt (a)*, P. C. Cropper (a), L. Shao (a) and C. I. Goodier (b)

Affiliations

(a) Institute of Energy and Sustainable Development, Queens Building, De Montfort University, The Gateway, Leicester LE1 9BH, UK

(b) School of Civil and Building Engineering, Loughborough University, UK

* Corresponding author Tel: +44(0)116 257 7886; Fax: +44(0)116 257 7981. Email address: sporritt@dmu.ac.uk (Stephen Porritt)

\section{ABSTRACT}

Extreme weather events, including heat waves, are predicted to increase in both frequency and severity over the coming decades. Low house building rates and a growing population mean there is a need to adapt existing dwellings. Research presented here uses dynamic thermal simulation to model the effect of passive heat wave mitigating interventions for UK dwellings. Interventions include a range of additions and modifications to solar shading, insulation and ventilation.

Results are presented for typical end and mid terrace houses, with four orientations, two occupancy profiles and using weather data from the 2003 heat wave. Results show the effectiveness of interventions that reduce solar gains through the building fabric, such as external wall insulation and solar reflective coatings. Internal wall insulation is shown to be less effective and can increase the overheating problem in some cases. Control of solar gains through glazing, using shutters and fixed shading, are also effective, particularly for south, east and west-facing rooms.

Results are also presented which demonstrate how it is possible to select combinations of interventions that both eliminate overheating and reduce space heating energy use. The cost of interventions is also considered in the final analysis.

\section{KEYWORDS}

Heat wave; housing; overheating; adaptation; retrofit; intervention; building simulation 


\section{INTRODUCTION}

Much of the focus for UK building refurbishment to date has concentrated on reductions to winter heating energy use. However, climate change projections from the UK Met Office [1] suggest that in addition to increased mean temperatures there are likely to be more frequent and more intense extreme weather events, including heat waves. The European heat wave in August 2003 claimed the lives of over 35,000 people, more than 2,000 of which were in the UK, with over 600 in London [2]. The victims were mostly elderly and vulnerable and the situation was exacerbated by the urban heat island effect in major cities. Temperatures recorded in London were up to $10^{\circ} \mathrm{C}$ higher than surrounding rural areas [3]. The UK Department of Health currently predict that a 9-day heat wave averaging $27^{\circ} \mathrm{C}$ in South East England would lead to over 3,000 immediate heat related deaths [4]. Monitored temperature data from a variety of London dwellings during the 2003 heat wave by Wright et al [5] showed that average indoor temperatures were $2.3{ }^{\circ} \mathrm{C}$ higher than the average outdoor temperature of $26.0^{\circ} \mathrm{C}$, with the peak indoor temperature in one apartment room reaching $39.2{ }^{\circ} \mathrm{C}$.

The housing stock in the UK is being replaced at a very low rate and it is estimated that over $70 \%$ of the dwellings that will be occupied in 2050 have already been built [6]. There is therefore a need to adapt existing dwellings to provide a safe and comfortable environment in a changing climate. The UK's Institute of Environmental Management and Assessment [7] recently reported that 90\% of local government departments were planning for adaptation to climate. Individual UK Government Departments have also recently published their latest climate adaptation plans [8], signalling a shift in emphasis towards policies which combine mitigation with adaptation.

These adaptation plans have generated a need for detailed information and data to aid decisionmaking. The Chartered Institution of Building Services Engineers (CIBSE) [9,10] has published guidance, addressing specifically the impact of climate change on the indoor environment. They considered occupied hours over the CIBSE comfort threshold temperatures of $26^{\circ} \mathrm{C}$ for bedrooms and $28{ }^{\circ} \mathrm{C}$ for other living areas [10] for a range of buildings. CIBSE modelled a combination of building interventions over a whole summer for each case, using predicted future climate scenarios. For each dwelling type in the report only one occupancy profile was used - a family, who were at work and school during daytime hours. Consideration of different occupancy types is also absent in other publications, including a technical report by the Energy Saving Trust [11], which suggests useful advice for designers, and a report by Arup for the Three Regions Climate Change Group [6]. They suggested interventions which may be retrofitted or, as in the case of higher thermal mass, are more applicable to new build.

The results of this research aim to provide detailed quantitative information to inform retrofit decision-making for both individual house owners and organisations responsible for multiple properties, including local authorities and housing associations. It is therefore important to consider the effect of interventions on both overheating reduction and annual space heating energy use. The cost of interventions may also be a barrier to uptake and is included in the final analysis.

Only passive interventions have been considered in this research, as they do not directly contribute to building energy consumption and its associated carbon emissions. The effect on the ranking order due to different resident and occupancy profiles was also investigated. 


\section{METHODOLOGY}

The research presented here expands on previous published work by quantifying the effect of a range of single and combined interventions, specifically during real heat wave periods that were known to cause health problems (including increased mortality). The term interventions covers a range of physical additions or adaptations to the building fabric as well as behavioural changes, such as modifying ventilation strategies. Table 1 shows the interventions applied in this research split into three categories: insulation, solar control and ventilation.

Table 1. Interventions modelled in the assessment (details in Table 4)

\section{Insert Table 1.}

Computer simulation was used to assess the effectiveness of the interventions listed in Table 1. In order to perform the large number (tens of thousands) of parametric simulations required to model a range of dwelling types, building orientations and occupancy profiles, for single and combined interventions for the research project, it was necessary to choose a simulation tool which could be run in a batch simulation configuration. EnergyPlus v6.0 [12] was used under the control of jEPlus [13], a Java based parametric control interface. EnergyPlus was used to perform dynamic thermal simulations, enabling hourly prediction of the thermal conditions in a multi-zone building model by an iterative calculation process. EnergyPlus, developed by the US Department of Energy, has a comprehensive feature set, is widely used in both academia and industry (through third party interfaces) and has been tested against the IEA BESTest building load and HVAC tests [14]. DesignBuilder (version 2.3.5) [15] was used to construct building geometry and to produce EnergyPlus input data files (IDFs). Initial previously reported results [16], using some different model settings and assumptions, were obtained using Integrated Environmental Solutions Virtual Environment (IES-VE) software [17].

\subsection{Targeted dwellings}

South East England is predicted to be the UK region at greatest risk from summertime overheating [1] and within this region, dwellings in Greater London are expected to be at higher risk due to the urban heat island effect. The recent English House Condition Survey (EHCS) [18] shows the most common dwelling types for London and South East England (Figure 1) and has therefore been used to select appropriate dwelling types for this study.

\section{Insert Figure 1.}

Figure 1. Dwellings in London and South East England by type and age

Terraced housing accounts for $29 \%$ of London dwellings, with solid wall being the most common type of construction (approximately one third of terraced houses in London were built before 1919 [18]). Solid wall terraced housing is therefore one of the dwelling types chosen for this research and is the type for which results are presented in this paper.

\subsection{Building simulation model and settings}

The simulation model presented in this paper represents a row of three $19^{\text {th }}$ Century terraced houses, located in a Greater London suburban area (Figure 2).

\section{Insert Figure 2.}

Figure 2. Simulation model of terraced houses (NE and SE elevations) 
The houses are constructed from solid brick walls, with a suspended timber ground floor and a claytiled roof. Each house comprises a living room (at the front and north-facing for the base case model), dining room, kitchen, bathroom and three bedrooms. The main bedroom (Bed 1) is located at the rear (and therefore south-facing) and the kitchen and bathroom are located within an extension at the rear (Figure 3). The layout used is typical of terraced houses of the period in the UK and constitutes a large proportion of ageing existing stock requiring renovating and updating. Designs will however vary in practice.

\section{Insert Figure 3.}

Figure 3. Terraced house floor plans of ground and first floor

As a result of a wide range of previous refurbishment and modernisation programmes, the thermal properties of these dwellings are likely to vary substantially. The EHCS dataset was used to establish the construction and insulation properties for the base case simulation model and to ensure that they are representative of terraced housing of this type. It was found that over $50 \%$ of the surveyed pre1919 terraced houses from the dataset have more than 50\% double-glazing installed and of those with double-glazing the majority $(83 \%)$ have uPVC window frames. Therefore, in the base case computer model it has been assumed that the original single glazing has been replaced with uPVC framed uncoated double-glazing. The survey data indicates that the most common level of loft insulation is between $75 \mathrm{~mm}$ and $150 \mathrm{~mm}$. $100 \mathrm{~mm}$ of glass fibre loft insulation (consistent with joist level insulation with $100 \mathrm{~mm}$ ceiling joists) has therefore been assumed. It has also been assumed that a rear extension, containing the kitchen and bathroom, has been added during the latter part of the $20^{\text {th }}$ century. This would be a common addition to houses of the period and is constructed with uninsulated cavity walls and a solid concrete ground floor. The construction and thermal properties are summarised in Table 2.

Table 2. Terraced house base case model construction and thermal properties

\section{Insert Table 2.}

It has been assumed that the houses have had their living room fireplaces fitted with sealed gas heaters. The lack of open fireplaces and the presence of double-glazing reduces the background infiltration rate from that when constructed. The infiltration is estimated to be 0.7 air changes per hour $(\mathrm{ACH})$, calculated using a method from the Building Research Establishment Domestic Energy Model [19]. The rear extensions have solid concrete floors and therefore a lower background infiltration of $0.5 \mathrm{ACH}$.

Internal gains for people and appliances were determined using CIBSE [10] and ASHRAE [20] guideline values. Metabolic rates were set as follows: seated adults $108 \mathrm{~W} /$ person; sleeping adults 72 $\mathrm{W} /$ person and sleeping children $54 \mathrm{~W} /$ person. Appliance gains of $150 \mathrm{~W}$ for the living rooms (TV) and $100 \mathrm{~W}$ for children's bedrooms (computers) were set to follow occupied hours (switched off when asleep). Low energy lighting was assumed and 30W lighting heat gains included for living rooms in the evenings.

EnergyPlus provides two methods of predicting ventilation within the buildings; calculated ventilation and scheduled ventilation. The calculated ventilation option requires knowledge of the maximum openable area of each external opening and detailed information about cracks, their size and characteristics, to enable the software to calculate the infiltration and ventilation rates. British Standard 5925:1991 [21] recommends that the openable area should be at least one twentieth of the room floor area. However, surveys of properties show that in many cases the openable area is far 
greater, with large variations from house to house. The alternative approach to modelling the ventilation and infiltration is to use the scheduled ventilation option, which sets fixed rates for given space types and is the method used in this research. The UK Government's Standard Assessment Procedure for Energy Rating of Dwellings [22] provides effective air change rates (ACH) for dwellings in hot weather, derived from procedures in BS 5925. For rooms in two storey dwellings, where cross ventilation is possible (living rooms, dining rooms, kitchens), the maximum effective air change rate when windows are fully open is $8 \mathrm{ACH}$ and where cross ventilation is not possible (bedrooms and bathrooms where doors are closed when occupied) the maximum is $5 \mathrm{ACH}$. For the base case model during occupied hours, window ventilation commences when the room operative temperature reaches $22{ }^{\circ} \mathrm{C}$ and increases linearly until reaching the maximum value by $28^{\circ} \mathrm{C}$. This is the simulation control method used in CIBSE Report TM36 [9], which also agrees with observations on window opening threshold temperatures from field surveys conducted by Rijal et al [23].

\subsection{Weather data}

To simulate the effect of a heat wave on a building and its occupants, weather data is required that contains a suitable heat wave period. In order to achieve this, three options were considered. The first was to use a weather file from a European location such as Rome [24] or Milan [25] to approximate the South East England climate later this century. However, the different latitudes of these locations would affect solar shading calculations. Humidity and wind speed values may also be different to those expected in the UK. The second option, the approach adopted in the CIBSE TM36 report [9] and in the earlier stages of this research, is to use future predicted UK weather data derived using a morphing procedure by Belcher et al [26]. This provides weather data with elevated summer temperatures, which provides a basis for predicting whole summer overheating. However, the morphed years are based on current test reference years (TRYs), constructed from typical months from a number of years (avoiding extreme months containing heat wave periods, e.g. June/July 1976 and August 2003), or design summer years (DSYs), which are hot years (not the hottest), but which may not contain heat wave periods. Consequently, in order to find suitable heat wave periods approaching the severity of real heat waves experienced in recent years, it was necessary to use future predicted weather files for periods towards the end of the century (2080s). The third option, and the one used to provide the results presented, is to use weather data from years containing real heat wave periods in the UK (1976, 1995 and 2003), to assess the effectiveness of interventions during extreme heat waves that are known to have caused increased mortality. The results presented in this paper were produced using 2003 weather data for London Heathrow, which was obtained from the British Atmospheric Data Centre [27]. Figure 4 shows the dry bulb temperature from a section of the weather file, including the 9 -day heat wave period of the $4^{\text {th }}-12^{\text {th }}$ August, 2003, where daytime temperatures peaked at over $37^{\circ} \mathrm{C}$ and intervening night time temperatures did not drop below $18{ }^{\circ} \mathrm{C}$. Table 3 contains key weather data for each day of the heat wave period.

\section{Insert Figure 4.}

Figure 4. Simulation weather period dry bulb temperature

Table 3. August 2003 heat wave period weather data

\section{Insert Table 3}

\subsection{Modelled passive cooling interventions}

The aim of this research is to evaluate a range of passive interventions (Table 1) that can reduce or eliminate the need for mechanical cooling. However, not all interventions considered are appropriate for every dwelling type. For example, adding additional external or internal wall insulation to a 
modern dwelling with highly insulated cavity walls may be difficult to justify. There may be other obstacles in the form of planning constraints, which could limit the range of potential interventions that change the external appearance. Cost may also be a limiting factor for the uptake of some interventions and is addressed later (Section 3.3).

Insulation interventions were selected to comply with current UK Building Regulations for extensions to existing properties [28] and it has been assumed that some improvement to draught proofing would occur during the installation of wall insulation. Window shading interventions (blinds, shutters and curtains) were selected from the EnergyPlus materials database. The effect of blocking solar radiation was modelled by adding overhangs, to provide fixed shading above the south, east and west-facing windows. The effect of a range of overhang sizes was considered by using solar shading modelling. An overhang depth (horizontal projection from the wall) of $1.0 \mathrm{~m}$ was found to block most of the direct solar radiation for south-facing windows during the summer period, whilst still being a practical size. Larger overhangs would be required to totally block solar radiation on east and west windows, but it was found that fitting the $1.0 \mathrm{~m}$ devices still had some benefit. Ground floor windows on east and west facades at the rear of the dwellings had 2.0m overhangs to simulate the effect of awnings. However, these were not considered for windows at the front of the dwellings due to practicality issues (UK terraced houses are generally constructed at the edge of the pavement, next to the road).

If the outside air temperature is warmer than the room air temperature overheating will increase as the windows open. The window rules intervention prevents windows from opening if that condition is met. Residents may desire the breeze from open windows on hot days, particularly if crossventilation is possible. Some evaporative skin cooling may be achieved in that situation, but this cannot be predicted using the simulation methods adopted and has not been included in this research.

The cost of interventions will, in practice, vary significantly and individual householders are likely to pay more than large organisations due to economies of scale. No single source of cost information could be found that covered all of the modelled interventions. Spon's [29] provided estimated installed costs for solar coatings (wall and roof) and fixed external shading devices. A report for the Energy Saving Trust [30] provided estimated costs for wall and loft insulation and the Royal Institution of Chartered Surveyors [31] was used to derive glazing costs. Commercial quotes were obtained for internal blinds and external shutters. Night ventilation was assumed to require either window security upgrades or vent and fan installation, for which a cost was estimated. The costs used (Table 4) are for the U.K., excluding tax, and were obtained between 2009 and 2011. They are for guidance only and should not be relied upon for estimating project costs.

Table 4. Modelled interventions details

\section{Insert Table 4.}

\subsection{Simulation variants}

Computer simulations for the two house models (end terrace and mid terrace) were carried out for the base case version and then with the addition of each single intervention in turn. This process was carried out for the terrace facing north (living rooms on the north side, main bedrooms on the south side) and then rotated to face east, south and west in turn. For each orientation the simulations were carried out for two occupancy profiles, the first assumed occupation by a typical family of two adults and two children, leaving the houses unoccupied during the daytime. The second assumed 
occupation by an elderly couple, at home during the daytime. Table 5 shows the occupancy profiles for the living rooms and main bedrooms.

Table 5. Occupied hours for living rooms and main bedrooms Insert Table 5.

\subsection{Combined interventions}

A parameter tree was constructed using jEPlus [32] to select combinations of interventions for simulation. Certain combinations can be eliminated, for example only one type of wall insulation would be chosen, not both types together. This resulted in a total of 1,536 simulations for each orientation. This was repeated for the two occupancy profiles, producing a total of 12,288 simulations. The simulations were carried out for the 2003 heat wave period and for annual simulations to calculate the total space heating energy use for each dwelling. A simple heating system was modelled and the zone sensible heating results were reported by EnergyPlus.

\subsection{Overheating criteria}

The operative temperatures for the living room and bedroom 1 of both the left hand end terrace house and the mid terrace house (Figure 2) were computed for every hour over the 9-day heat wave period. The operative temperature combines the room air temperature and the mean radiant temperature from the room surfaces to provide a thermal comfort index temperature.

CIBSE [10] recommend that thermal comfort threshold temperatures of $28{ }^{\circ} \mathrm{C}$ for living rooms and $26{ }^{\circ} \mathrm{C}$ for bedrooms should not be exceeded for more than $1 \%$ of occupied hours. Adaptive threshold temperatures are proposed in British Standard EN 15251 [33], based on the running mean outdoor temperature and derived from studies in naturally ventilated office buildings. These adaptive thresholds may be applied to similarly constructed dwellings for daytime activity, but there is no guidance for their application in bedrooms at night, where sleep may be impaired above $24^{\circ} \mathrm{C}$ [10]. They are also based on limited data for outdoor running mean temperatures greater than $25^{\circ} \mathrm{C}$, which was exceeded towards the end of the 2003 heat wave. When the outdoor running mean temperature reaches $25^{\circ} \mathrm{C}$ the upper limit indoor operative temperature for healthy adults in an existing building would be $31^{\circ} \mathrm{C}$ [32]. This is greater than the current CIBSE guideline peak temperature allowed for office spaces of $30^{\circ} \mathrm{C}$ [10]. CIBSE formed an overheating task force in 2007 to produce a new Technical Memorandum addressing adaptive thermal comfort. The delay in publication reflects the uncertainties involved, though it is hoped to use the adaptive approach in future research when the issues have been resolved.

The results presented in this paper show the effect of the interventions on the number of degree hours over $26^{\circ} \mathrm{C}$ for bedrooms and $28^{\circ} \mathrm{C}$ for living rooms for the heat wave period. The number of degree hours arguably gives a better representation of the severity of the overheating problem than simply recording hours over the threshold temperature by quantifying the extent to which the threshold has been exceeded. This method allows comparisons between the relative effects of interventions and has been used in other research (e.g. [11,34]). 


\section{RESULTS AND DISCUSSION}

Dynamic thermal simulations were carried out for the base case model and then for the range of interventions listed in Tables 1 and 3. The weather file (Figure 4) contains an extreme heat wave period lasting 9 days $\left(4^{\text {th }}-12^{\text {th }}\right.$ August $)$, where the maximum day temperature peaked at $37.2{ }^{\circ} \mathrm{C}$, with night temperatures not dropping below $18.4{ }^{\circ} \mathrm{C}$. The results for the base case model were compared to monitored air temperature data from London houses recorded during the 2003 heat wave [5]. Although there are no exact matches for house type within the monitored dwellings, there is a solid walled semi-detached house, with $90 \%$ double-glazing and an east-facing living room. Table 6 shows that there is a good agreement between the base case simulated temperatures and those from the monitored dwelling.

Table 6. Monitored and simulated living room temperatures

\section{Insert Table 6.}

The simulations also produced operative temperatures for the living rooms and main bedrooms for each hour over the 9-day heat wave period. The results presented in subsequent sections show the effect of the interventions, during occupied hours, on the number of degree hours over the CIBSE comfort threshold temperatures of $28{ }^{\circ} \mathrm{C}$ for the living rooms and $26{ }^{\circ} \mathrm{C}$ for the main bedrooms for the duration of the heat wave.

\subsection{Intervention effect for main bedrooms}

Figures 5 and 6 show the effect of the interventions on overheating exposure measured by the number of degree hours over $26{ }^{\circ} \mathrm{C}$ for the main bedrooms in the end terrace and mid terrace houses. Each chart shows the effect of the interventions for the two occupancy profiles, with the terrace oriented such that the main bedrooms face (a) north, (b) south, (c) east and (d) west. The lighter portion of each bar shows the increase in the number of degree hours of overheating under the elderly occupancy profile.

\section{Insert Figure 5.}

Figure 5. End terrace bedroom 1 single interventions for family and elderly profiles

The building orientation was found to have a substantial impact on overheating exposure, varying by almost $100 \%$ between different orientations. The greatest overheating is seen to occur when the bedroom windows face west for the end terrace house. In this case, the bedroom has walls facing west and south, thereby being exposed to solar radiation for most of the day. Coating the walls with a high performance solar reflective paint (light walls) was found to be the most effective intervention for the end terrace house in all cases, reducing the number of degree hours over $26^{\circ} \mathrm{C}$ by between $50 \%$ and $60 \%$. This intervention is also effective for the mid terrace house, but to a lesser extent (38\%-43\% reduction) due to the smaller wall area. Using the same coating on the roof tiles (light roof) is also effective, but less so than on the walls for the end terrace house.

External wall insulation, added to reduce heat loss through the walls in the heating season, also shields the outer brick surface from direct solar radiation, whilst leaving the internal plastered walls exposed to provide radiative cooling. This is seen to have the greatest effect for the south-facing end terrace bedroom (with the second wall east-facing) where a $49 \%-51 \%$ reduction in degree hours is observed. 
Internal wall insulation was found to be less effective than external wall insulation, this is thought to be due to the exclusion of coolth stored in the thermal mass resulting in a loss of radiative cooling from the internal faces of the external walls and also because occupant heat gains are being retained within the rooms. For east-facing end terrace bedrooms and west facing mid terrace bedrooms the addition of internal wall insulation is seen to increase the number of degree hours compared to the base case by up to $14 \%$ for elderly occupancy.

\section{Insert Figure 6.}

Figure 6. Mid terrace bedroom 1 single interventions for family and elderly profiles

External shutters were found to reduce the number of degree hours by up to $39 \%$ and, though more expensive, are more effective than internal blinds (up to $20 \%$ reduction) and curtains $(15 \%$ reduction). Internal window shading devices cannot prevent some of the solar radiation being trapped inside the room and converted to long wave radiation. Fixed shading over the south, east and west windows was found to be effective, reducing the number of degree hours by $15-16 \%$ for the end terrace house and up to $28 \%$ for the mid terrace house. Replacing the existing standard double-glazed windows with low-e triple-glazing would be a very expensive option, even if part of a standard refurbishment cycle. However, they were found to be effective, reducing overheating by up to $22 \%$.

The window rules ventilation strategy was not found to have a great effect on bedroom overheating because during bedroom occupied hours the outside air temperature is rarely higher than the bedroom temperature. The night ventilation intervention, though applied to ground floor windows, still had a benefit for bedroom overheating by cooling the building as a whole. Increasing the level of loft insulation does reduce annual space heating energy use and also has a small benefit (around 4\%) in reducing overheating in bedrooms.

\subsection{Intervention effect for living rooms}

Figures 7 and 8 show the effect of the interventions on the number of degree hours over $28{ }^{\circ} \mathrm{C}$ for the living rooms in the end terrace and mid terrace houses. The occupancy profiles for the living rooms are very different, with the family assumed to be out of the house during the day and the elderly couple at home, occupying the living rooms during the hotter daytime hours.

The charts illustrate the much higher number of degree hours of overheating experienced by the elderly occupants. The effect of orientation was also found to be highly significant, with the highest number of degree hours occurring when the living room windows face east for the end terrace house. In this case the living room has external walls facing east and south. The ranking order of the interventions is much less affected by the occupancy profile, although there are significant differences, notably in the ranking of external wall insulation

\section{Insert Figure 7.}

Figure 7. End terrace living room single interventions for family and elderly profiles

\section{Insert Figure 8.}

Figure 8. Mid terrace living room single interventions for family and elderly profiles

When the living rooms are north-facing, the overheating problem was found to be very small for the family occupancy profile, being virtually non-existent in the mid terrace house. However, overheating was found to be more significant for the elderly occupancy profile, where the 
overheating rises to an average of 7.6 degree hours per day for the end terrace living room. The north-facing end terrace living room also has an east-facing external wall and the most effective interventions for the elderly occupancy profile was found to be light walls (69\% reduction in degree hours) and external wall insulation (63\% reduction). For the mid terrace house, with less external wall area, the window rules intervention was found to be the most effective, reducing degree hours by $85 \%$ by excluding warm outside air during the hottest parts of the day. Ground floor internal doorways were assumed to be open during the daytime. Therefore, interventions that reduce heat gains in the dining rooms and kitchens at the rear of the dwellings also have some effect on living rooms at the front.

Night ventilation of the ground floor rooms cools the thermal mass of the solid walls and provides a radiative cooling benefit that persists into the hotter daytime period, reducing degree hours in the north-facing mid terrace living room by $67 \%$ for the family profile. The effectiveness of night ventilation for the elderly profile was found to be reduced due to the windows opening during the hotter (occupied) parts of the day.

For south and west-facing living rooms the most effective intervention was found to be external shutters, reducing overheating by up to $71 \%$ (south-facing mid terrace with family profile). Fixed shading was also found to be very beneficial, particularly for south-facing living rooms, producing a $54 \%-58 \%$ reduction in degree hours.

The addition of external wall insulation for west-facing living rooms had a much lower effect than for other orientations, reducing degree hours by $20 \%$ for the end terrace house (where the second wall is north-facing) and $22 \%$ for the mid terrace house. However, internal wall insulation actually increased overheating in the end terrace house by $21 \%$ for this orientation. Figure 9 shows the effect of internal wall insulation on the end terrace living room operative temperature, assuming the elderly occupancy profile, showing how the operative temperature increases above the base case value during the occupied period.

\section{Insert Figure 9.}

Figure 9. Effect of internal wall insulation on operative temperature

\subsection{Combined interventions considering cost and heating energy use}

The effect on overheating reduction of combining the single interventions presented above was then assessed systematically. It is beyond the scope of this paper to report all the possible combinations of interventions, considering each orientation for both the mid and end terrace houses. Two case studies are presented here to demonstrate how the assessment process and simulation results may be used to inform retrofit decision-making. Full results for the terrace houses and other dwelling types will be presented in a full report as part of the CREW project (see Acknowledgements).

Figure 10 shows scatter plots of the effectiveness of the combined interventions for (a) the end terrace house facing west with the elderly occupancy profile and (b) the mid terrace house facing north with the family occupancy profile. In addition, the approximate cost of the combined interventions and the effect on the annual space heating energy use associated with them are shown graphically in the plots. 


\section{Insert Figures 10 (a) and (b)}

Figure 10. Degree hours over threshold temperatures for living room and main bedroom combined, with cost and space heating energy use for (a) end terrace, front west, elderly profile and (b) mid terrace, front north, family profile

Figure 10 shows the combined overheating degree hours experienced for a whole day, taking into account living room and bedroom occupied periods, and shows how the total overheating experienced by the elderly occupants in the end terrace house is over twice that for the family in the mid terrace house.

Table 7. Combined interventions.

(House a) End terrace, front west, elderly occupancy

Insert Table 7 (a)

(House b) Mid terrace, front north, family occupancy

Insert Table 7 (b)

Specific combinations of interventions (case studies), indicated by letters A to E in Figures 10 (a) and (b), are summarised in Table 7. In both cases the most economical interventions (case study B) were found to be the control of window opening during hotter parts of the day (window rules), whilst keeping curtains closed during the daytime. However, there are practical issues that must be considered. The occupants need to know when the outside air temperature has risen above the inside air temperature and the possible need to use electric lighting if curtains are closed. The occupants may also find closing curtains unacceptable due to the loss of external view. As this is a behavioural change its effectiveness is dependent upon the occupants carrying out the procedure.

The annual simulations take account of beneficial solar gains through the building fabric, particularly in spring and autumn, which can reduce space heating energy use. However, these gains are reduced by the addition of fixed shading and use of solar reflective paints. Case studies $\mathrm{C}$ show that it is possible to reduce overheating to very low levels, but at the expense of increased space heating energy use (up 6\% in House a and $8 \%$ in House b). The benefit of fixed shading above south-facing windows is observed in House $b$, which has south-facing windows in both the dining room and main bedroom.

Case studies D demonstrate how it is possible to reduce overheating to a very low level in House a and to zero in House b, whilst also reducing space heating energy use by $48 \%$ (House a) and $41 \%$ (House b), though this would require a higher investment (around $£ 9-12 \mathrm{k}$ ). The results in Figure 10 also show that additional costly interventions provide little further reduction in overheating or space heating energy use. For example the installation of low e triple glazing in addition to all the other insulation improvements only reduces space heating energy use by a further $4 \%$, at an additional cost of around $£ 5 \mathrm{k}$.

Case study $\mathrm{E}$ is an example of a combination of interventions which reduce space heating energy use but have a poor impact on overheating, being either ineffective (House b) or increasing the overheating problem (House a). 


\section{CONCLUSIONS}

Local authorities, housing providers, designers and owners need accurate technical guidance to target their resources when considering adaptation for climate change. This is particularly important when adapting dwellings for vulnerable groups, such as the elderly, where heat stress can be dangerous due to their inability to either control or remove themselves from their environment. This research shows the importance of considering the type of occupants and their corresponding occupancy profiles as well as the dwelling construction details when choosing the most appropriate interventions. The simulation results show the potential for reducing overheating during heat wave periods for a range of single and combined passive interventions. Occupancy type was found to have a very significant impact on overheating exposure. This is particularly pronounced for living rooms, where overheating exposure is often 3 times higher for elderly occupancy than for family occupancy. This is because elderly residents occupy the dwellings during the hottest parts of the day and are often subject to disproportionately higher overheating for the extra hours of occupancy. Building orientation has a similarly large impact on overheating exposures, with differences between two orientations sometimes exceeding $100 \%$.

Interventions relating to exposed wall surfaces, such as coating with solar reflective paint and external wall insulation, were found to be very effective, particularly for the end terrace house where the external wall area is greater. Controlling ventilation to prevent excess warm outside air entering the dwelling during the hottest parts of the day was found to be effective for elderly occupants and the benefit of cooling the building fabric overnight with night ventilation is observed, resulting in lower operative temperatures throughout the daytime period. As a result of practical considerations, this may be most effectively achieved through the use of automatically controlled ventilation openings.

The use of shutters, blinds and curtains was found to be effective in reducing overheating, with external shutters being especially effective, particularly for south-facing living rooms. However, there are practical issues with the use of these interventions due to loss of view and the possible need to use artificial lighting during the day. External fixed shading in the form of overhangs or awnings was also found to be effective, especially for south-facing rooms.

The choice of wall insulation type was found to be important, with internal wall insulation being less effective than external wall insulation, even producing an increase in overheating for some scenarios (west-facing living rooms and east-facing bedrooms). However, if the internal wall insulation is fitted in conjunction with other solar control measures the overheating can be effectively reduced whilst also reducing annual space heating energy use.

The presented work further considered the costs of the selected interventions and their implications for annual space heating energy use. It was found that beneficial solar gains through windows and the building fabric during the heating season may be reduced by the addition of fixed shading or by coating external surfaces with solar reflective paints.

It should also be noted that implementation of some of the interventions may not be possible due to external factors, such as local planning constraints and visual impact (changes to the external appearance), obstruction (overhangs) or noise, security and/or air quality (night ventilation). 
This report has presented simulation results for two house types, an end and mid-terrace house. Further research is currently being carried out to address a wider range of dwelling types and occupancy profiles.

This research presents information about the effectiveness and relative costs of a range of passive overheating mitigation measures, in a highly user friendly single diagram to allow easy identification of the best and most appropriate combinations of interventions.

\section{ACKNOWLEDGEMENTS}

This research is funded by the Engineering and Physical Sciences Research Council (EPSRC) as part of the "Community Resilience to Extreme Weather" (CREW) project (grant number EP/F036442/1). Their financial support is gratefully acknowledged. Further details are available at www.extreme-weather-impacts.net A prototype web toolkit has been developed to demonstrate the research output, which can be accessed at: $\underline{w w w . i e s d . d m u . a c . u k / c r e w}$

\section{REFERENCES}

[1] G.J. Jenkins, J.M. Murphy, D.S. Sexton, J.A. Lowe, P. Jones, C.G. Kilsby, UK Climate Projections: Briefing Report. Met Office Hadley Centre, Exeter, UK, 2009.

[2] H. Johnson, R.S. Kovats, G. McGregor, J. Stedman, M. Gibbs, H. Walton, The impact of the 2003 heat wave on daily mortality in England and Wales and the use of rapid weekly mortality estimates. Eurosurveillance, 10(7-9) (2005) 168-171.

[3] Greater London Authority, Mayor of London's draft climate change adaptation strategy (2010). Online: www.london.gov.uk/climatechange/strategy Last accessed 27th January, 2012.

[4] Department of Health and the Health Protection Agency, Health effects of climate change in the UK, 2008, available online:

www.dh.gov.uk/en/Publicationsandstatistics/Publications/PublicationsPolicyAndGuidance/DH_0807 $\underline{02}$ Last accessed 27th January, 2012.

[5] A.J. Wright, A.N. Young, S. Natarajan, Dwelling temperatures and comfort during the August 2003 heat wave, Building Services Engineering Research and Technology, 26(4) (2005) 285-300.

[6] Your home in a changing climate (Arup for Three Regions Climate Change Group). Greater London Authority. ISBN 978184781133 2, London, 2008.

[7] The Institute of Environmental Management and Assessment. Special Report: Adapting to Climate Change Survey, Lincoln, UK, 2009.

[8] Government departmental adaptation plans. Available online: www.defra.gov.uk/environment/climate/government/departmental-adaptation-plans/ Last accessed 27th January, 2012.

[9] CIBSE TM36: Climate change and the indoor environment: Impacts and adaptation. (Principal authors J.N. Hacker, M.J. Holmes, S.B. Belcher, G.D. Davies, Chartered Institute of Building Services Engineers, London, 2005. 
[10] CIBSE Guide A: Environmental Design. Chartered Institute of Building Services Engineers, London, 2006.

[11] Energy Saving Trust CE129: Energy efficiency best practice in housing: Reducing overheating - a designer's guide. Technical report, Energy Saving Trust, London, 2005.

[12] US Department of Energy, EnergyPlus simulation software:

http://apps1.eere.energy.gov/buildings/energyplus/ Last accessed 27th January, 2012.

[13] jEPlus parametric simulation control interface, Available online:

www.iesd.dmu.ac.uk/ yzhang/wiki/doku.php?id=software:java:jeplus Last accessed 27th January, 2012.

[14] US Department of Energy, EnergyPlus testing and validation:

http://apps1.eere.energy.gov/buildings/energyplus/energyplus_testing.cfm Last accessed 27th January, 2012.

[15] DesignBuilder simulation software: www.designbuilder.co.uk Last accessed 27th January, 2012.

[16] S.M. Porritt, L. Shao, P.C. Cropper, C.I. Goodier, Occupancy patterns and their effect on interventions to reduce overheating in dwellings during heat waves. Proceedings of Conference: Adapting to Change: New Thinking on Comfort. Cumberland Lodge, Windsor, UK, 9-11 April 2010. London: Network for Comfort and Energy Use in Buildings, http://nceub.org.uk

[17] Integrated Environmental Solutions Virtual Environment: www.iesve.com Last accessed 27th January, 2012.

[18] English house condition survey public dataset. Available on CD-Rom from EHCS Project Team, CLG, Eland House, Bressenden Place, London SW1E 5DU. Product code 09ACST06138, 2009.

[19] Building Research Establishment, BREDEM-12 Model description 2001 update. BRE, Garston, UK, 2002.

[20] ASHRAE Handbook: Fundamentals, American Society of Heating, Refrigerating and AirConditioning Engineers, Atlanta, GA, USA, 2009.

[21] British Standard 5925:1991 Code of practice for ventilation principles and designing for natural ventilation, British Standards Institute, London, 1991.

[22] The Government's Standard Assessment Procedure for Energy Rating of Dwellings 2009 edition. Building Research Establishment (for UK Department of Energy and Climate Change), Garston, UK, 2010.

[23] H.B. Rijal, P. Tuohy, F. Nicola, M.A. Humphreys, A. Samuel, J. Clarke, Development of an adaptive window-opening algorithm to predict the thermal comfort, energy use and overheating in buildings. Journal of Building Performance Simulation 1(1) (2008)17-30. 
[24] P. de Wilde, R. Yaqub, M. Beck, Uncertainties in predicting the impact of climate change on thermal performance of domestic buildings in the UK. Building Services Engineering Research and Technology, 29(1) (2008) 7-26.

[25] M.R. Gaterell, M.E. McEvoy, The impact of climate change uncertainties on the performance of energy efficiency measures applied to dwellings. Energy and Buildings, 37 (2005) 982-995.

[26] S. Belcher, J. Hacker, D. Powell, Constructing design weather data for future climates. Building Services Engineering Research and Technology, 26 (1) (2005) 49-61.

[27] British Atmospheric Data Centre (BADC), Didcot, UK, http://badc.nerc.ac.uk Last accessed 27th January, 2012.

[28] The Building Regulations 2000: Conservation of Fuel and Power Part L1B. Conservation of fuel and power in existing dwellings (revised April 2006). The Stationery Office (Office of the Deputy Prime Minister), London. ISBN-13 9781859462188.

[29] Spon's Architects' and Builders' Price Book, $136^{\text {th }}$ Edition, D. Langdon (Ed.), Spon Press, UK, 2011, ISBN: 978-0-415-58845-4.

[30] The Energy Saving Trust. Solid Wall Insulation Supply Chain Review. Purple Market Research for the Energy Saving Trust and the Energy Efficiency Partnership for Homes. May, 2009.

[31] The greener homes price guide. Royal Institution of Chartered Surveyors Building Cost Information Service (BCIS), London, 2009, ISBN: 9781904829676.

[32] Y. Zhang, I. Korolija, Performing complex parametric simulations with jEPlus, Proceedings of conference: SET2010 - 9th International Conference on Sustainable Energy Technologies. Shanghai, China. 24-27 ${ }^{\text {th }}$ August, 2010.

[33] British Standard EN 15251:2007 Indoor environmental input parameters for design and assessment of energy performance of buildings addressing indoor air quality, thermal environment, lighting and acoustics. British Standards Institute, London, 2008.

[34] M. Orme, J. Palmer, S. Irving, Control of over-heating in well insulated housing (FaberMaunsell Ltd.). In Proceedings of the CIBSE/ASHRAE Conference in Building Sustainability, Value and Profit, Edinburgh, pp24-26, September, 2003. 
Table 1. Interventions modelled in the assessment (details in Table 3)

\begin{tabular}{lll}
\hline Category & Intervention \\
\hline Insulation & - & Increase loft insulation from $100 \mathrm{~mm}$ to $250 \mathrm{~mm}$ thick \\
& - & Add external wall insulation to all external walls \\
- & Add internal wall insulation to all external walls \\
\hline Colar & - & Add reflective internal window blinds, closed during the day \\
& - & Add external window shutters, closed during the day \\
& - & Close curtains during the day \\
& - & Add $1.0 \mathrm{~m}$ deep overhangs above south, east and west-facing \\
& & windows (2.0m deep awnings to rear east and west-facing \\
& ground floor windows) \\
& - Coat all external walls with high performance solar reflective \\
& paint (lower solar absorptivity) \\
& - Coat all roof tiles with high performance solar reflective paint \\
& (lower solar absorptivity) \\
& - Replace existing double glazing with low-e triple glazing to \\
& reflect solar radiation \\
\hline Ventilation & Night ventilation: allow ground floor ventilation with outside \\
& air at night \\
& - Window rules: prevent window opening if outside air is \\
& warmer than inside air
\end{tabular}


Table 2. Terraced house base case model construction and thermal properties

\begin{tabular}{llll}
\hline Element & Details & $\begin{array}{l}\text { U-Value } \\
\text { (W/m² })\end{array}$ & $\begin{array}{l}\text { Solar } \\
\text { Absorptivity }\end{array}$ \\
\hline Main house walls & Solid brick (215mm) with internal plaster (13mm) & 2.12 & 0.6 \\
Rear extension walls & Brick and block with uninsulated cavity and plaster & 1.43 & 0.6 \\
Roof & $\begin{array}{l}\text { Clay tiles with joist level glass fibre insulation } \\
\text { (100m) }\end{array}$ & 0.36 & 0.8 \\
Internal partitions & Solid brick (105mm) with plaster (13mm) each side & 0.5 \\
$\begin{array}{l}\text { Ground floor main } \\
\text { house }\end{array}$ & $\begin{array}{l}\text { Suspended timber with underlay and carpet, cavity } \\
\text { (300mm) to ground (clay to 500mm) }\end{array}$ & 0.84 & 0.6 \\
$\begin{array}{l}\text { Ground floor } \\
\text { extension }\end{array}$ & $\begin{array}{l}\text { Solid concrete (100mm) uninsulated to ground (clay } \\
\text { to 500mm) }\end{array}$ & 1.25 & - \\
Windows & $\begin{array}{l}\text { Pre-2002 double glazing, plain float glass (6mm) } \\
\text { with air gap (12mm), uPVC frame (15\% of window } \\
\text { area), solar transmission (SHGC) 0.708, light } \\
\text { transmission 0.812 }\end{array}$ & $\begin{array}{l}\text { (inc. frame) } \\
\text { Wooden }\end{array}$ & \\
\hline
\end{tabular}


Table 3. August 2003 heat wave period weather data

\begin{tabular}{lcrrrrrrrrr}
\hline & & Day 1 & Day 2 & Day 3 & Day 4 & Day 5 & Day 6 & Day 7 & Day 8 & Day 9 \\
\hline $\begin{array}{l}\text { Dry bulb temp } \\
{ }^{\circ} \mathrm{C}\end{array}$ & Max & 31.6 & 31.3 & 35.2 & 29.7 & 30.7 & 34.8 & 37.3 & 33.1 & 29.6 \\
& Min & 16.7 & 19.0 & 21.7 & 18.2 & 18.9 & 18.5 & 20.2 & 20.0 & 18.9 \\
$\begin{array}{l}\text { Relative humidity } \\
\%\end{array}$ & Max & 83 & 86 & 80 & 88 & 85 & 89 & 83 & 86 & 86 \\
& Min & 41 & 37 & 31 & 45 & 45 & 28 & 18 & 38 & 49 \\
$\begin{array}{l}\text { Atmospheric } \\
\text { pressure } \mathrm{kPa}\end{array}$ & Ave & 102.1 & 102.0 & 101.7 & 101.8 & 101.7 & 101.6 & 101.4 & 101.5 & 101.7 \\
$\begin{array}{l}\text { Direct normal } \\
\text { radiation Wh/m }\end{array}$ & Max & 686 & 652 & 718 & 649 & 632 & 785 & 718 & 641 & 704 \\
$\begin{array}{l}\text { Diffuse horizontal } \\
\text { radiation Wh/m }\end{array}$ & Max & 208 & 296 & 227 & 290 & 374 & 167 & 197 & 342 & 294 \\
$\begin{array}{l}\text { Wind speed ms } \\
-1\end{array}$ & Max & 6.7 & 6.7 & 5.7 & 5.7 & 4.6 & 4.1 & 9.3 & 6.2 & 4.6 \\
& Min & 1.0 & 2.1 & 1.5 & 2.1 & 1.0 & 0.5 & 0 & 2.6 & 1.5 \\
\hline
\end{tabular}


Table 4. Modelled interventions details

$\begin{array}{lll}\text { Category Intervention } & \text { Description } & \begin{array}{l}\text { Estimated } \\ \text { Cost (f) }\end{array}\end{array}$

\begin{tabular}{|c|c|c|c|}
\hline \multirow[t]{3}{*}{ Insulation } & Loft insulation & $\begin{array}{l}\text { Increase loft insulation to } 250 \mathrm{~mm} \text { to achieve U-value of } \\
0.16 \mathrm{~W} / \mathrm{m}^{2} \mathrm{~K}\end{array}$ & $0.2 \mathrm{k}$ \\
\hline & $\begin{array}{l}\text { External wall } \\
\text { insulation }\end{array}$ & $\begin{array}{l}\text { Addition of } 60 \mathrm{~mm} \text { phenolic foam and } 20 \mathrm{~mm} \text { render to } \\
\text { outside face of external walls, U-value } 0.35 \mathrm{~W} / \mathrm{m}^{2} \mathrm{~K} \text {, } \\
\text { background infiltration reduced to } 0.5 \mathrm{ACH}\end{array}$ & $\begin{array}{l}14.0 \mathrm{k}(\mathrm{end}) \\
8.5 \mathrm{k} \text { (mid) }\end{array}$ \\
\hline & $\begin{array}{l}\text { Internal wall } \\
\text { insulation }\end{array}$ & $\begin{array}{l}\text { Addition of } 60 \mathrm{~mm} \text { phenolic foam and } 13 \mathrm{~mm} \text { plasterboard } \\
\text { to inside face of external walls, U-value } 0.35 \mathrm{~W} / \mathrm{m}^{2} \mathrm{~K} \text {, } \\
\text { background infiltration reduced to } 0.5 \mathrm{ACH}\end{array}$ & $\begin{array}{l}7.7 \mathrm{k}(\mathrm{end}) \\
4.7 \mathrm{k}(\mathrm{mid})\end{array}$ \\
\hline \multirow[t]{7}{*}{$\begin{array}{l}\text { Solar } \\
\text { Control }\end{array}$} & Internal blinds & $\begin{array}{l}\text { High reflectivity slats, solar transmittance } 0 \text {, solar } \\
\text { reflectance } 0.8 \text {, conductivity } 0.9 \mathrm{~W} / \mathrm{m}-\mathrm{K} \text {, closed from } \\
0900 \text { to } 1800\end{array}$ & $1.6 \mathrm{k}$ \\
\hline & $\begin{array}{l}\text { External } \\
\text { shutters }\end{array}$ & $\begin{array}{l}\text { High reflectivity slats, solar transmittance } 0 \text {, solar } \\
\text { reflectance } 0.8 \text {, conductivity } 0.9 \mathrm{~W} / \mathrm{m}-\mathrm{K} \text {, closed from } \\
0900 \text { to } 1800\end{array}$ & $3.3 \mathrm{k}$ \\
\hline & $\begin{array}{l}\text { Internal } \\
\text { curtains }\end{array}$ & $\begin{array}{l}\text { Close weave medium drapes, solar transmittance } 0.05 \text {, } \\
\text { solar reflectance } 0.3 \text {, material conductivity } 0.1 \mathrm{~W} / \mathrm{m}-\mathrm{K} \text {, } \\
\text { closed from } 0900 \text { to } 1800\end{array}$ & $\begin{array}{l}0 \\
\text { (already } \\
\text { installed) }\end{array}$ \\
\hline & Fixed shading & $\begin{array}{l}\text { Add } 1.0 \mathrm{~m} \text { deep overhangs above south, east and west } \\
\text { windows ( } 2.0 \mathrm{~m} \text { deep awnings for east and west ground } \\
\text { floor rear windows) }\end{array}$ & $\begin{array}{l}1.3 \mathrm{k}-2.2 \mathrm{k} \\
\text { (orientation) }\end{array}$ \\
\hline & Light walls & $\begin{array}{l}\text { Coat external walls with high performance solar reflective } \\
\text { paint to reduce solar absorptivity to } 0.15\end{array}$ & $\begin{array}{l}1.3 \mathrm{k}(\mathrm{end}) \\
0.8 \mathrm{k}(\mathrm{mid})\end{array}$ \\
\hline & Light roof & $\begin{array}{l}\text { Coat roof tiles with high performance solar reflective } \\
\text { paint to reduce solar absorptivity to } 0.15\end{array}$ & $0.9 \mathrm{k}$ \\
\hline & $\begin{array}{l}\text { Low e triple- } \\
\text { glazing }\end{array}$ & $\begin{array}{l}\text { Replace double-glazing with low emissivity coated triple- } \\
\text { glazing: } 3 \text { x } 3 \mathrm{~mm} \text { panes with } 12 \mathrm{~mm} \text { air gaps, inner and } \\
\text { outer panes coated, solar transmission }(\mathrm{SHGC}) 0.472 \text {, } \\
\text { light transmission } 0.661 \text {, U-value } 1.6 \mathrm{~W} / \mathrm{m}^{2} \mathrm{~K}\end{array}$ & $5.1 \mathrm{k}$ \\
\hline \multirow[t]{2}{*}{ Ventilation } & $\begin{array}{l}\text { Night } \\
\text { ventilation }\end{array}$ & $\begin{array}{l}\text { Ventilation of ground floor rooms with cooler outside } \\
\text { night air at } 8 \text { air changes per hour (may require low power } \\
\text { fans if security or noise is an issue, preventing window } \\
\text { opening) }\end{array}$ & $0.4 \mathrm{k}$ \\
\hline & Window rules & $\begin{array}{l}\text { Prevent windows from being opened (reduce ventilation } \\
\text { to background infiltration only) if outside air temperature } \\
\text { is greater than inside air temperature }\end{array}$ & 0 \\
\hline
\end{tabular}


Table 5. Occupied hours for living rooms and main bedrooms

\begin{tabular}{lll}
\hline & Living rooms & Main bedrooms \\
\hline Family & $1800-2300$ & $2300-0730$ \\
Elderly Couple & $0900-2230$ & $2230-0730$ \\
\hline
\end{tabular}


Table 6. Monitored and simulated living room temperatures

\begin{tabular}{llll}
\hline Temperature $\left({ }^{\circ} \mathrm{C}\right)$ & Min & Mean & Max \\
\hline Monitored temperatures & 24.0 & 27.0 & 31.9 \\
$($ Wright et al, 2005) & & & \\
Simulation model: Family profile & 22.9 & 27.1 & 31.0 \\
Elderly profile & 23.0 & 27.7 & 32.2 \\
\hline
\end{tabular}


Table 7. Combined interventions.

(House a) End terrace, front west, elderly occupancy

\begin{tabular}{|c|c|c|c|}
\hline $\begin{array}{l}\text { Case } \\
\text { study } \\
\text { (Fig.10a) }\end{array}$ & Interventions and approximate cost & $\begin{array}{l}\text { Degree hours } \\
\text { over threshold } \\
\left({ }^{\circ} \mathrm{C}\right)\end{array}$ & $\begin{array}{l}\text { Annual space } \\
\text { heating energy } \\
\left(\mathrm{kWh} / \mathrm{m}^{2} / \mathrm{yr}\right)\end{array}$ \\
\hline A & Base case & 169 & 161 \\
\hline B & Window rules and curtains $(£ 0)$ & 99 & 161 \\
\hline $\mathrm{C}$ & $\begin{array}{l}\text { Light walls, light roof, night ventilation, window } \\
\text { rules, curtains ( } £ 2.6 \mathrm{k})\end{array}$ & 10 & 171 \\
\hline $\mathrm{D}$ & $\begin{array}{l}\text { Internal wall insulation, light walls, light roof, loft } \\
\text { insulation, night ventilation, window rules, fixed } \\
\text { shading, curtains (£12.0k) }\end{array}$ & & 83 \\
\hline $\mathrm{E}$ & Internal wall insulation (£7.7k) & & 82 \\
\hline
\end{tabular}

(House b) Mid terrace, front north, family occupancy

\begin{tabular}{llll}
\hline $\begin{array}{l}\text { Case } \\
\text { study } \\
\text { (Fig.10b) }\end{array}$ & Interventions and approximate cost & $\begin{array}{l}\text { Degree hours } \\
\text { over threshold } \\
\left({ }^{\circ} \mathrm{C}\right)\end{array}$ & $\begin{array}{l}\text { Annual space } \\
\text { heating energy } \\
\left(\mathrm{kWh} / \mathrm{m}^{2} / \mathrm{yr}\right)\end{array}$ \\
\hline A & Base case & 66 & 108 \\
B & Window rules and curtains (£0) & 45 & 108 \\
$\mathrm{C}$ & $\begin{array}{l}\text { Light walls, light roof, window rules, fixed shading, } \\
\text { curtains (£2.9k) }\end{array}$ & 3 & 117 \\
D & $\begin{array}{l}\text { Internal wall insulation, light roof, loft insulation, } \\
\text { night ventilation, window rules, shutters (£9.4k) }\end{array}$ & 0 & 64 \\
$\mathrm{E}$ & Internal wall insulation (£4.7k) & 199 & 65 \\
\hline
\end{tabular}


Figure 1. Dwellings in London and South East England by type and age

Figure 2. Simulation model of terraced houses (NE and SE elevations)

Figure 3. Terraced house floor plans of ground and first floor

Figure 4. Simulation weather period dry bulb temperature

Figure 5. End terrace bedroom 1 single interventions for family and elderly profiles

Figure 6. Mid terrace bedroom 1 single interventions for family and elderly profiles

Figure 7. End terrace living room single interventions for family and elderly profiles

Figure 8. Mid terrace living room single interventions for family and elderly profiles

Figure 9. Effect of internal wall insulation on operative temperature

Figure 10. Degree hours over threshold temperatures for living room and main bedroom combined, with cost and space heating energy use for (a) end terrace, front west, elderly profile and (b) mid terrace, front north, family profile 


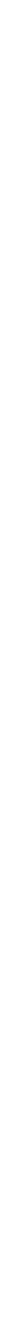




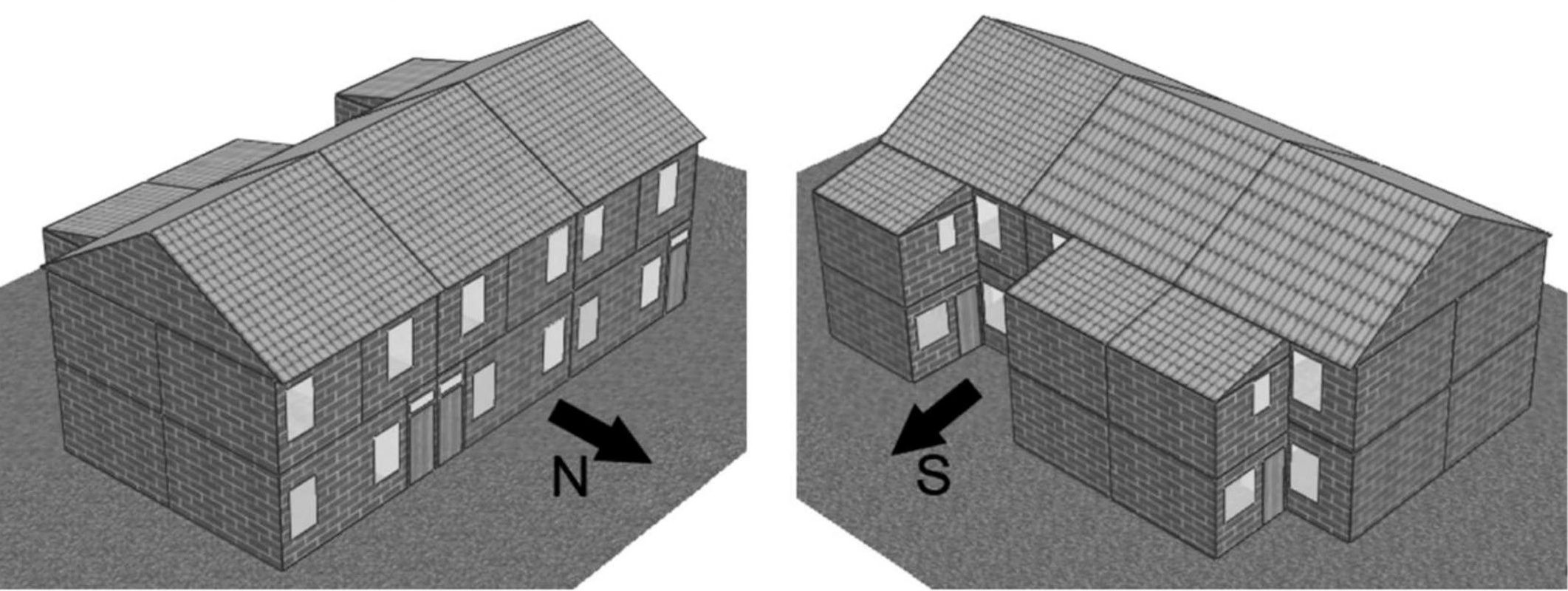

Figure 2

ACCEPTED MANUSCRIPT 
Ground Floor

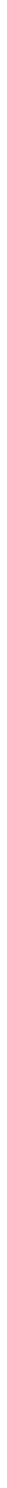

First Floor
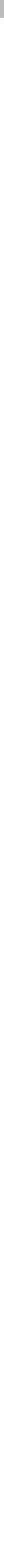
Figure 4

ACCEPTED MANUSCRIPT

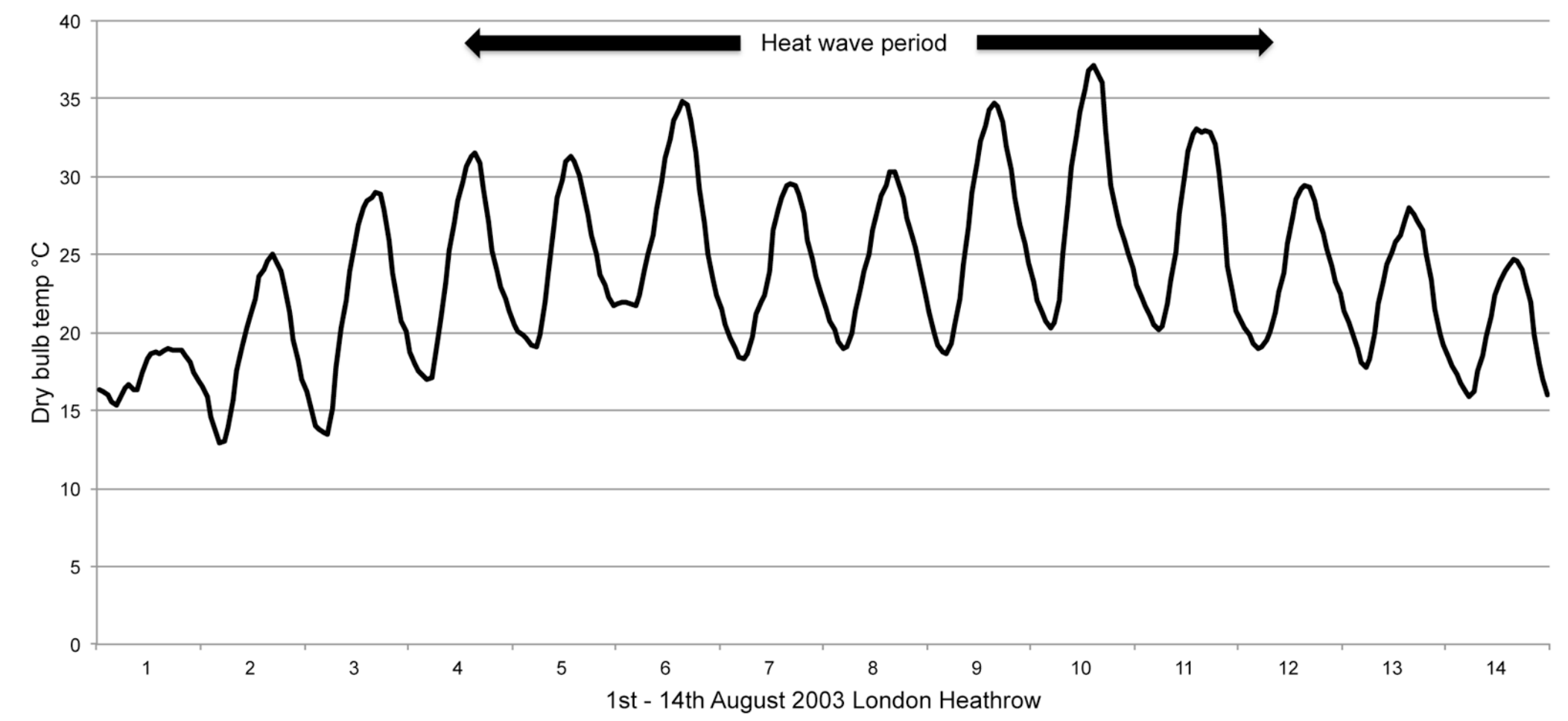


(a) End terrace living room facing north

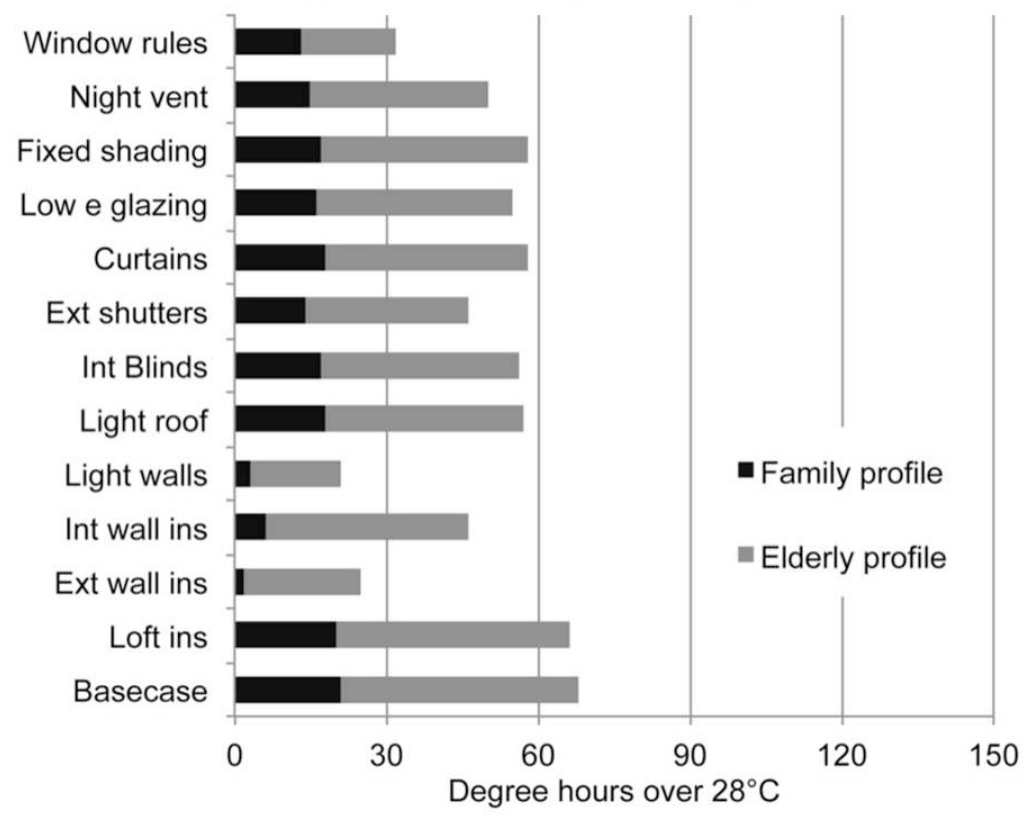

(c) End terrace living room facing east

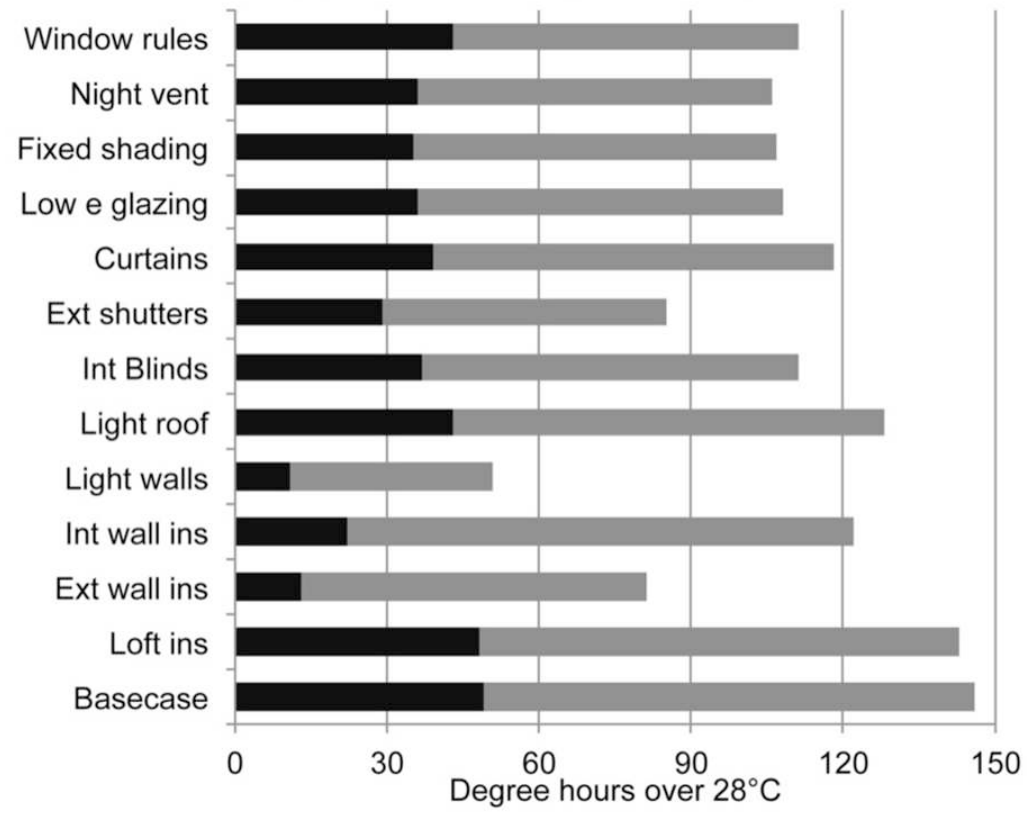

(b) End terrace living room facing south

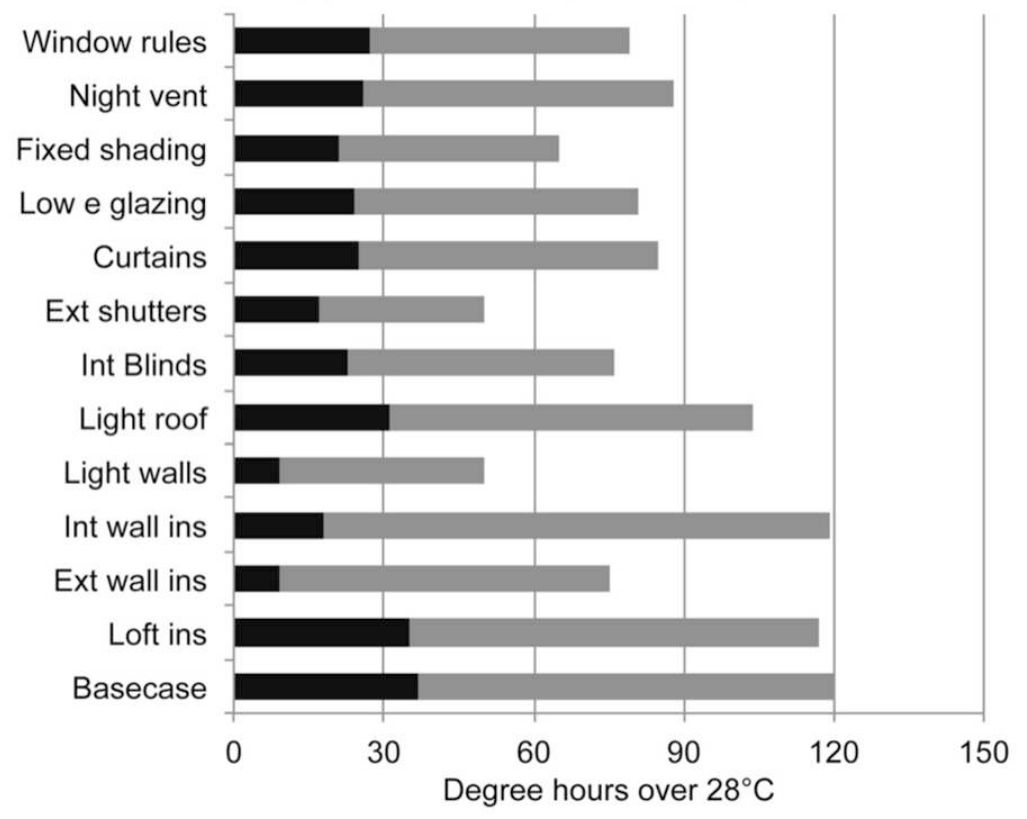

(d) End terrace living room facing west

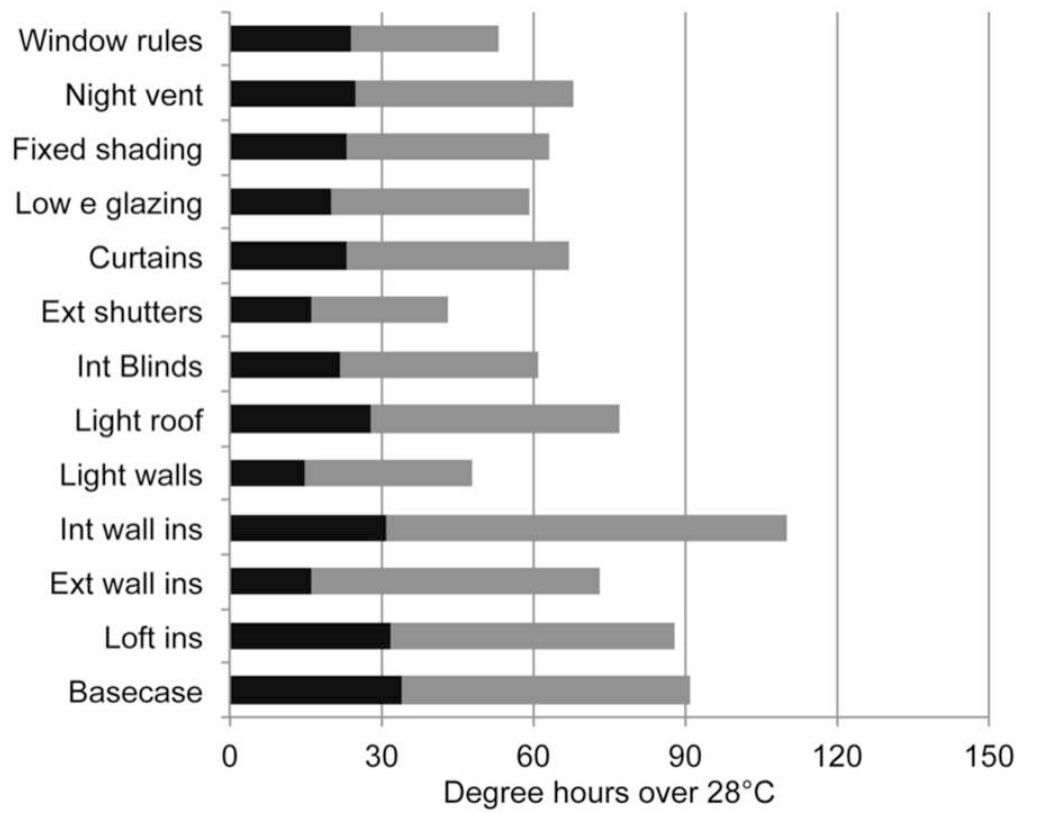




\section{Figure $20 \theta^{(a)}$}

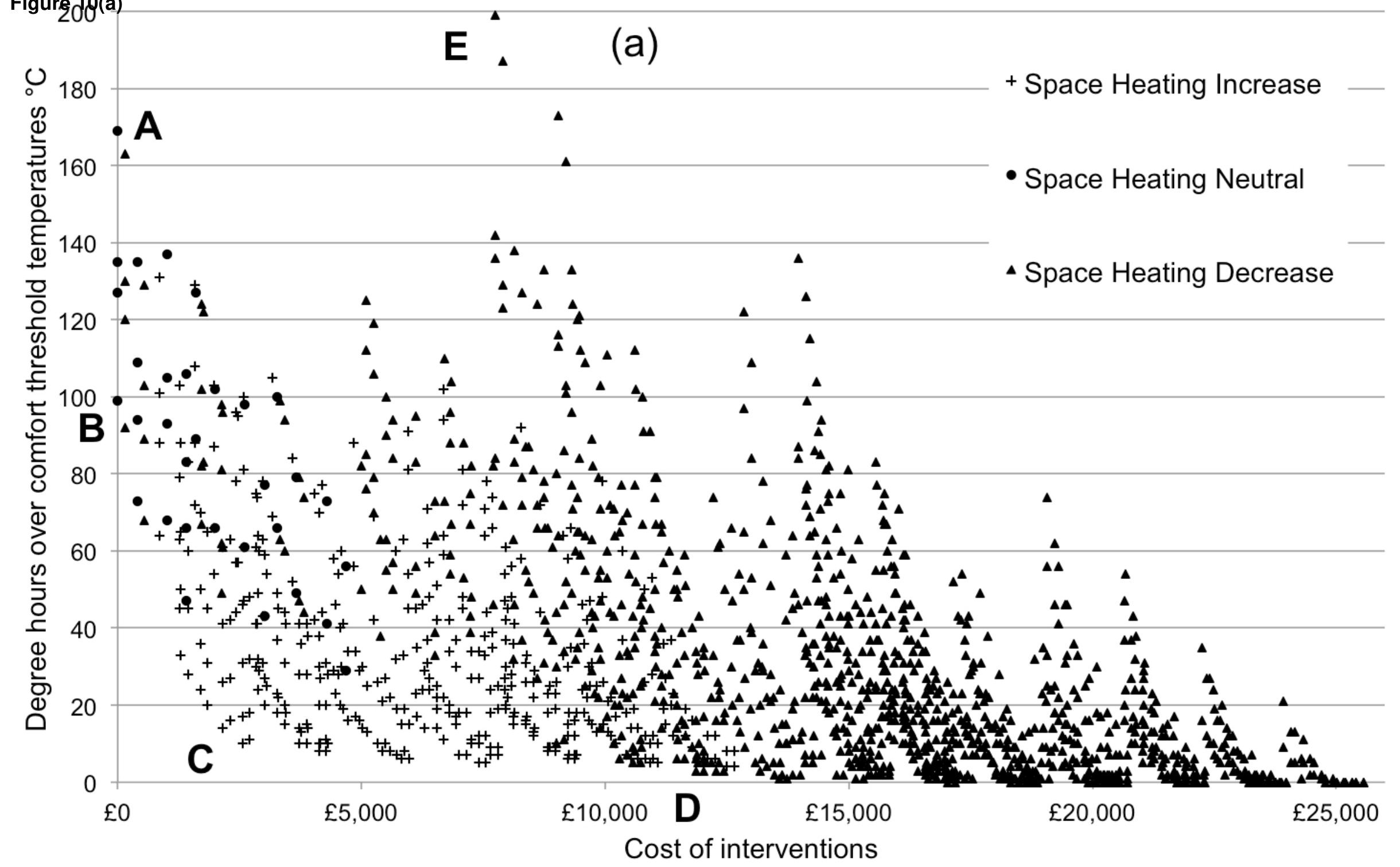


Figure $7 g(b)$

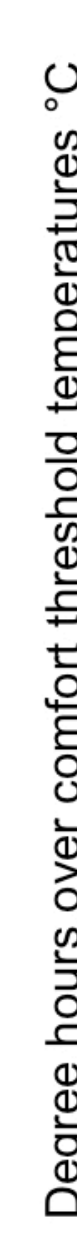

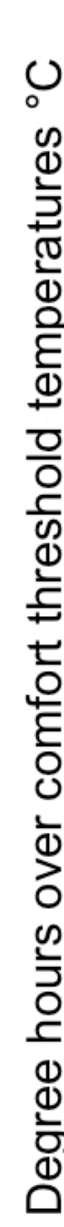

60

50

(c)

40

30 $\cdot A$
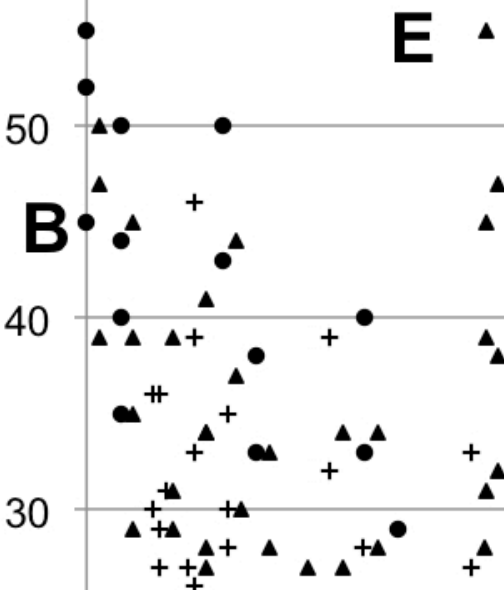

(b)

Key to case study interventions:

A Base case dwelling

B Best no cost interventions

C Best low cost interventions, but with space heating penalty

D Best higher cost interventions, good for overheating and with space heating benefit

E Interventions which are poor for overheating, but have a space heating benefit

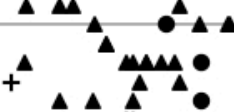

A4.

$\bullet \Delta$

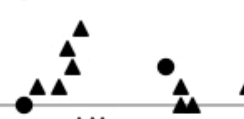

$\triangle$

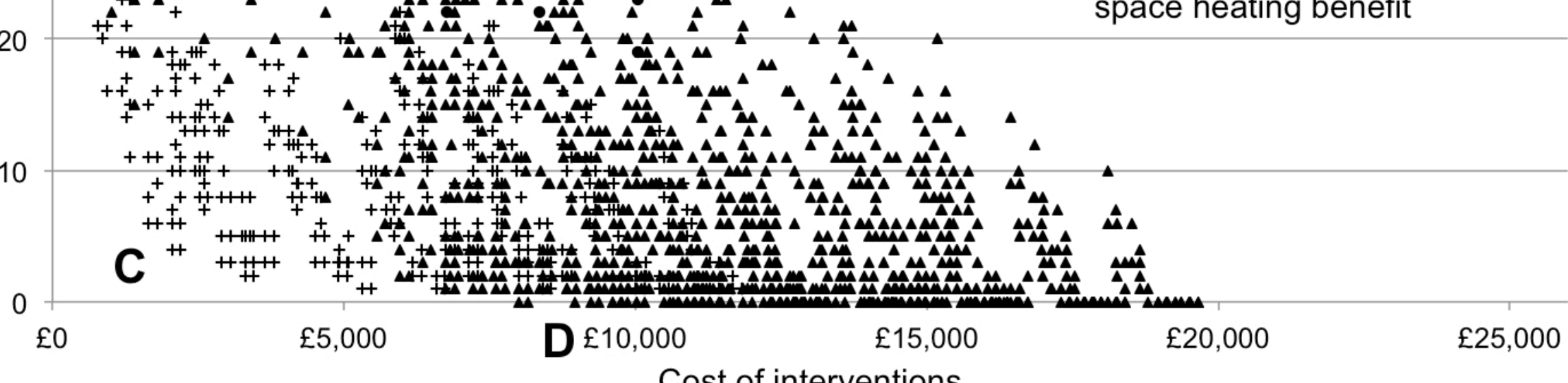

Cost of interventions 
Ranking of interventions to reduce dwelling overheating during heat waves

Porritt et al

Highlights:

- Interventions to reduce overheating in UK dwellings are modelled

- The effect of building orientation and occupancy are investigated

- The effect of interventions on space heating energy use and cost of interventions is included in the final analysis

- Careful selection of combined interventions can reduce overheating whilst also reducing energy use 